\title{
Pencarian Informasi Dakwah Islam melalui Media Online Pada Masa Pandemi COVID-19 bagi Komunitas Muslim
}

\author{
Ditha Prasanti', Kismiyati El Karimah ${ }^{2}$ \\ ${ }^{1}$ Program Studi Ilmu Komunikasi, ${ }^{2}$ Program Studi Manajemen Komunikasi, Fakultas Ilmu Komunikasi, \\ Universitas Padjadjaran \\ Jl Raya Bandung Sumedang KM 21 Jatinangor, 45363, Indonesia \\ Email: ditha.prasanti@unpad.ac.id ${ }^{1 *}$; miyaelkarimah@gmail.com² \\ *Corresponding author
}

\begin{abstract}
During the COVID-19 pandemic, individuals used social media to find the latest information, but a lot of information about COVID-19 was disturbing. The purpose of this study is to 1) find out the reasons for seeking Islamic da'wah information through online media during the COVID-19 pandemic, 2) reveal the impact of the COVID-19 pandemic period for seeking Islamic da'wah information for Muslim teenage communities X, 3) knowing the process of seeking Islamic da'wah information done by the Muslim teenager community $\mathrm{X}$ through online media. The research method used is a case study of COVID-19, with data collection techniques in the form of literature studies, observations, and in-depth interviews with Muslim youth communities in Bandung. The results of the research conducted show that: 1) the reason for seeking Islamic da'wah information originated from the flood of information about the COVID-19 pandemic, thus encouraging the community to find solutions, 2) the impact of the COVID-19 pandemic period causing the Muslim youth community to be active and selective in seeking information da'wah Islam through online media, 3) the process of searching for Islamic da'wah information starting from grouping needs, making schedules and online discussion groups, using online discussion platforms or platforms such as Google Meet, Zoom Meeting, and WhatsApp Video Call. The period of the COVID-19 pandemic has encouraged the community to remain active in seeking Islamic da'wah information. The substance of this research contributes in the form of new policy recommendations for adolescents in seeking information through online media to be selective so as not to harm others. Keywords: COVID-19 Information; Islamic Da'wah; Online Media; Search
\end{abstract}

\begin{abstract}
Abstrak
Masa pandemi COVID-19 menjadikan individu memanfaatkan media sosial untuk mencari informasi terbaru, namun banyak informasi yang diperoleh tentang COVID-19 yang meresahkan. Tujuan penelitian ini untuk 1) mengetahui alasan pencarian informasi dakwah islami melalui media online pada masa pandemi COVID-19, 2) mengungkapkan dampak masa pandemi COVID-19 bagi pencarian informasi dakwah islami bagi komunitas remaja muslim X, 3) mengetahui proses pencarian informasi dakwah islam yang dilakukan komunitas remaja muslim X melalui media online. Metode penelitian yang digunakan adalah studi kasus COVID-19, dengan teknik pengumpulan data berupa studi literatur, observasi, dan wawancara mendalam dengan komunitas remaja muslim di Bandung. Hasil penelitian yang dilakukan menunjukkan bahwa: 1) alasan pencarian informasi dakwah islam berawal dari adanya kebanjiran informasi tentang pandemi COVID-19 sehingga mendorong komunitas tersebut untuk mencari solusinya, 2) dampak masa pandemi COVID-19 menyebabkan komunitas remaja muslim aktif dan selektif dalam pencarian informasi dakwah islam melalui media online, 3) proses pencarian informasi dakwah islam tersebut mulai dari mengelompokkan kebutuhan, membuat jadwal dan kelompok diskusi online, menggunakan wadah atau platform diskusi online seperti Google Meet, Zoom Meeting, dan WA Video Call. Masa pandemi COVID-19 telah mendorong komunitas tersebut tetap aktif dalam pencarian informasi dakwah Islam. Substansi penelitian ini memberikan kontribusi berupa rekomendasi kebijakan baru para remaja dalam mencari informasi melalui media online harus selektif agar tidak merugikan lainnya.
\end{abstract}

Kata Kunci: COVID-19; Informasi; Dakwah Islam; Media Online; Pencarian

\section{Pendahuluan}

Masa pandemi Covid-19 sebagai sebuah situasi yang telah mampu mengubah situasi dan kebiasaan hidup individu pada masa kini. Salah satunya adalah situasi dan perubahan dalam pencarian informasi. Berbagai informasi pun membanjiri kehidupan individu terutama tentang pandemi COVID-19. Data terbaru yang diperoleh dari kalbaronline pada November 2020, adanya kecemasan sosial yang dialami remaja 
pada masa pandemi COVID-19 mengakibatkan adanya sejumlah perubahan besar pada semua aspek kehidupan terutama pencarian informasi. Hal tersebut diungkapkan oleh Fatria (2020) bahwa kecemasan sosial tersebut dapat membawa efek negatif terhadap kesehatan mental bagi siapapun yang mengalaminya.

Data lainnya dari Republika.id bahwa Direktur Utama RSJ Jabar Elly Marliyani menyampaikan adanya peningkatan durasi penggunaan gawai selama masa pandemi COVID-19. Berdasarkan penelitian RSCM Fakultas Kesehatan Universitas Indonesia (UI) pada April-Juni 2020, ada perubahan waktu rata-rata penggunaan gawai hingga 11,6 jam per hari dan peningkatan kecanduan internet pada remaja sebesar 19,3 persen. Kondisi tersebut sejatinya memicu terjadinya potensi stres bagi semua kalangan, mulai dari orang tua, remaja, maupun anak-anak (Sujarwoko, 2020).

Fenomena tersebut justru bertolak belakang dengan kegiatan yang dilakukan oleh subjek penelitian ini, yaitu komunitas remaja muslim. Hal inilah yang menjadi kebaruan penelitian penulis, bahwa penggunaan media online yang kian meningkat dan menimbulkan kecemasan sosial, justru menjadi sebuah langkah dalam melakukan pencarian informasi dakwah islam, lagi-lagi melalui media online.

Selama pandemi COVID-19, ada kepanikan atau persoalan psikologis mental, ketakutan, atau kecemasan sosial yang dipaparkan oleh Fatria (2020) tersebut sehingga mayoritas remaja pun melakukan pencarian informasi melalui media online. Hal inipun yang dilakukan oleh sebagian kalangan seperti komunitas penggiat remaja muslim yang melakukan pencarian informasi dakwah Islam. Ternyata masa pandemi COVID-19 inipun tidak mematahkan komunitas remaja muslim bernama $\mathrm{X}$ dalam melakukan pencarian informasi dakwah Islam. Peneliti tertarik mengangkat komunitas remaja muslim tersebut, terutama dalam hal proses pencarian informasi tentang dakwah Islam yang dilakukannya. Masa pandemi COVID-19 tidak menjadi penghalang bagi komunitas tersebut dalam mencari informasi dakwah islam saat ini.
Atas dasar hal tersebut, peneliti juga melakukan studi literatur terdahulu tentang pencarian informasi pada masa pandemi COVID-19.

Penelitian pertama oleh Farooq, A., Laato, S., \& Islam (2020) mengungkapkan bahwa selama pandemi penyakit Coronavirus (COVID-19), pemerintah mengeluarkan pembatasan pergerakan dan menempatkan daerah-daerah ke karantina untuk memerangi penyebaran penyakit. Individu didorong untuk mengadopsi tindakan kesehatan pribadi seperti isolasi sosial. Informasi mengenai penyakit dan tindakan penghindaran yang disarankan didistribusikan melalui berbagai saluran termasuk media sosial, situs berita, dan email. Penelitian sebelumnya menunjukkan bahwa sejumlah besar informasi yang tersedia dapat membingungkan, berpotensi mengakibatkan kekhawatiran yang berlebihan dan informasi yang berlebihan.

Penelitian lain yang telah diungkapkan oleh Galanakis (2020) bahwa Organisasi Kesehatan Dunia (WHO) menyatakan wabah penyakit virus corona (COVID-19), yang secara luas disebut sebagai "virus korona" sebagai pandemi global. Ribuan infeksi dan kematian dilaporkan setiap hari. Artikel saat ini membahas sistem pangan di era krisis pandemi COVID-19. Hal ini memberikan wawasan tentang khasiat bahan bioaktif makanan dan herbal untuk mendukung sistem kekebalan manusia terhadap infeksi sebelum membahas kemungkinan penularan COVID-19 melalui rantai makanan. Ini juga menyoroti masalah keamanan pangan global yang timbul dari fakta bahwa sepertiga populasi dunia terkunci. Terakhir, ini menggarisbawahi pentingnya keberlanjutan dalam rantai makanan untuk menghindari atau mengurangi frekuensi krisis pangan dan kesehatan yang relevan di masa depan.

Penelitian lainnya Farooq, A., Laato, S., \& Islam (2020) juga mengungkapkan bahwa tidak ditemukan perbedaan persepsi antara orang yang tinggal sendiri dan mereka yang tinggal bersama keluarganya. Selama COVID-19, seringnya penggunaan media sosial berkontribusi pada informasi yang berlebihan dan kepedulian yang berlebihan di antara individu. Untuk meningkatkan 
motivasi individu untuk mengadopsi langkahlangkah pencegahan seperti isolasi diri, tindakan harus berfokus pada menurunkan biaya respons yang dirasakan individu selain memberi tahu mereka tentang parahnya situasi.

Berbagai data literatur tersebut menunjukkan fenomena kebanjiran informasi atau informasi berlebihan dalam media sosial menjadikan ramainya topik perbincangan berlangsung dalam berbagai platform media. Meskipun demikian, peneliti belum melihat ada yang mengangkat tentang pencarian informasi dakwah Islam bagi komunitas remaja muslim pada masa pandemic COVID-19.Padahal topiktersebutadalah halyang menarik, mengingat adanya informasi berlebihan yang melanda hampir seluruh masyarakat saat ini.

Pada penelitian lainnya menyampaikan bahwa media sosial memainkan peran penting selama pandemi seperti COVID-19, karena memungkinkan orang untuk berbagi berita serta pengalaman pribadi dan sudut pandang satu sama lain secara real-time dan global. Membangun lensa keterjangkauan dan teori beban kognitif, menyelidiki faktor motivasi dan atribut pribadi memengaruhi kelelahan media sosial dan berbagi informasi yang belum diverifikasi selama pandemi COVID-19. Orang tersebut mengembangkan model yang dianalisis menggunakan pemodelan persamaan struktural dan teknik jaringan saraf dengan data yang dikumpulkan dari orang dewasa muda di Bangladesh $(\mathrm{N}=433)$. Hasilnya menunjukkan bahwa orang-orang, yang didorong oleh promosi diri dan hiburan, dan mereka yang menderita kekurangan pengaturan diri, lebih mungkin untuk berbagi informasi yang belum diverifikasi. Eksplorasi dan religiusitas berkorelasi negatif dengan berbagiinformasi yang belum diverifikasi. Namun, eksplorasi juga meningkatkan kelelahan media sosial. Temuan penelitian tersebut menunjukkan tujuan penggunaan media sosial yang berbeda menimbulkan konsekuensi yang bermasalah, khususnya, peningkatan berbagi informasi yang salah (Islam, A. N., Laato, S., Talukder, S., \& Sutinen, 2020).
Infodemik sering kali termasuk rumor, stigma, dan teori konspirasi, telah umum terjadi selama pandemi COVID-19. Memantau data media sosial telah diidentifikasi sebagai metode terbaik untuk melacak rumor secara real time dan sebagai cara yang mungkin untuk menghilangkan informasi yang salah dan mengurangi stigma. Deteksi, penilaian, dan tanggapan terhadap rumor, stigma, dan teori konspirasi secara real time merupakan sebuah tantangan. Mengikuti dan memeriksa rumor, stigma, dan teori konspirasi terkait COVID-19 yang beredar di platform online, termasuk situs web agen pemeriksa fakta, Facebook, Twitter, dan surat kabar online, serta dampaknya terhadap kesehatan masyarakat. Informasi diekstrak antara 31 Desember 2019 dan 5 April 2020, dan dianalisis secara deskriptif. Peneliti melakukan analisis konten artikel berita untuk membandingkan dan membandingkan data yang dikumpulkan dari sumber lain. Islam, M. S., Sarkar, T., Khan, S. H., Mostofa Kamal, A. H., Hasan, S. M. M., Kabir, A., \& Chughtai (2020) mengidentifikasi 2.311 laporan rumor, stigma, dan teori konspirasi dalam 25 bahasa dari 87 negara. Klaim terkait dengan penyakit, penularan dan kematian (24\%), tindakan pengendalian (21\%), pengobatan dan penyembuhan (19\%), penyebab penyakit termasuk asal (15\%), kekerasan (1\%), dan lain-lain (20\%). Dari 2.276 laporan yang peringkat teksnya tersedia, 1.856 klaim salah $(82 \%)$. Misinformasi yang dipicu oleh rumor, stigma, dan teori konspirasi dapat memiliki implikasi serius pada individu dan komunitas jika diprioritaskan daripada pedoman berbasis bukti. Badan kesehatan harus melacak informasi yang salah terkait dengan COVID-19 secara real time, dan melibatkan komunitas lokal dan pemangku kepentingan pemerintah untuk menghilangkan prasangka kesalahan informasi.

Hasna, 2020 juga berpartisipasi aktif menuangkan pemikirannya tentang informasi di tengah pandemi COVID-19. Hasna mengangkat kata infodemik dalam tulisannya. Menurutnya, masyarakat mudah mengakses informasi terkait wabah melalui media sosial dan media online yang dapat diakses dengan cepat dan fleksibel. 
Infodemik dan banjir informasi di masa pandemi pun menjadi persoalan selanjutnya. Media digital di tengah pandemi COVID-19 membuat semakin banyaknya frekuensi informasi. Sehingga masyarakat tidak dapat memilah informasi yang benar dan informasi yang salah, hal tersebut dapat dikatakan sebagai banjir informasi. Berlebihnya informasi dapat dikatakan juga sebagai 'infodemik'. Infodemik menurut WHO (2020) adalah kelebihan jumlah informasi yang beredar dimana beberapa diantaranya akurat dan beberapa ada yang tidak, yang menyulitkan orang untuk menemukan sumber yang dapat dipercaya dan dapat diandalkan sebagai pedoman atau bimbingan, terlebih dalam kondisi ketika mereka membutuhkannya.

Sementara itu, peneliti juga memperoleh data pendukung lainnya tentang fenomena kebanjiran informasi ini. Ahmed (2020) mengungkapkan area krusial di mana kelebihan informasi dialami adalah konsumsi berita. Sumber dan format yang terus meningkat tersedia melalui kombinasi media tradisional dan baru (digital), termasuk media sosial. Dalam lingkungan yang kaya informasi dan media, memahami bagaimana orang mengakses dan mengelola berita selama epidemi kesehatan global seperti COVID-19 menjadi lebih penting. Penunjukan situasi saat ini sebagai infodemik telah menimbulkan kekhawatiran tentang kualitas, keakuratan, dan dampak informasi. Contoh kesalahan informasi adalah hal biasa, sebagian karena kecepatan dan sifat media sosial dan aplikasi perpesanan yang menyebar pada khususnya. Ahmed juga menunjukkan bahwa meskpuni pola konsumsi bervariasi, semua buku harian menunjukkan bahwa kemampuan pengguna untuk menavigasi lanskap berita dengan cara yang memenuhi kebutuhan mereka dipengaruhi oleh sumber berita; keandalan dan verifikasi platform; berbagi aktivitas; dan keterlibatan dengan berita

Penelitian yang dilakukan Saud, M., Mashud, M. I., \& Ida (2020) juga menguatkan topik penelitian yang diangkat peneliti tentang pencarian informasi melalui media online pada masa pandemic COVID-19. Saud memaparkan bahwa media sosial menjadi populer digunakan untuk mencari informasi medis dan menarik masyarakat umum untuk mengumpulkan informasi mengenai pandemi virus COVID-19 dari berbagai sudut pandang. Selama hari-hari ini, orang-orang terpaksa tinggal di rumah dan media sosial telah terhubung dan mendukung pembaruan kesadaran dan pandemi. Data juga dikumpulkan dari sumber sekunder seperti opini, literatur dan artikel ilmiah dari jurnal ternama. Jumlah total 348 tanggapan dikumpulkan dari responden melalui teknik random sampling, dan mayoritas responden menunjukkan sikap positif terhadap penggunaan media sosial sebagai instrumen informasi medis. Hasil penelitian tersebut menunjukkan bahwa media sosial telah digunakan untuk mencari dukungan sosial dari jaringan online responden dan teman offline, kerabat, dan kolega. Studi ini juga meneliti bahwa penggunaan platform media sosial dianggap mudah dan dapat diakses oleh setiap individu untuk dibagikan, diposkan, dan bereaksi terhadap informasi medis apa pun terkait pandemi. Hal ini disebabkan karena orang terus bekerja dari rumah, dan memastikan jarak sosial, sebagian besar pengguna telah melihat keluarga dan teman telah memberikan dukungan dan upaya untuk meningkatkan kesadaran dengan berbagi dan mengedarkan berbagai informasi dalam jaringan sosial tertutup mereka. Penelitian lainnya terkait dakwah dan pandemi COVID-19 telah dilakukan oleh beberapa peneliti yaitu Zaenuri (2020); Setyowati \& Cahya (2020); Muchlis (2020); Fauzi (2020); Hasan (2020).

Berdasarkan latar belakang masalah tersebut, maka peneliti tertarik untuk mengangkat fenomena pencarian informasi dakwah islam yang dilakukan komunitas remaja muslim yang ada di Bandung. Adapun tujuan penelitian ini adalah untuk mengetahui alasan pencarian informasi dakwah islami melalui media online pada masa pandemi COVID-19; mengungkapkan dampak masa pandemi COVID-19 bagi pencarian informasi dakwah islami bagi komunitas remaja muslim $\mathrm{X}$; dan mengetahui proses pencarian informasi dakwah islam yang dilakukan komunitas remaja muslim $\mathrm{X}$ melalui media online. 


\section{Metode Penelitian}

Metode penelitian ini adalah metode studi kasus, dengan pendekatan data kualitatif yang diperoleh dengan melakukan observasi, wawancara mendalam, dan studi dokumentasi. Sebagaimana diungkapkan oleh Creswell bahwa studi kasus sebagai sebuah metode penelitian yang membongkar sebuah fenomena realitas sosial yang memiliki keunikan secara mendalam (Creswell, J. W., \& Poth, 2016). Begitupun halnya dalam penelitian ini, peneliti memaparkan komunitas remaja muslim yang aktif melakukan pencarian informasi dakwah islam pada masa pandemic COVID-19 sebagai sebuah keunikan tersendiri.

Teknik observasi yang dilakukan oleh peneliti berlangsung secara online. Peneliti melakukan pengamatan dalam interaksi melalui media online yang terjadi dalam komunitas remaja muslim $\mathrm{X}$ khususnya ketika pencarian informasi dakwah Islam tersebut berlangsung. Demi menjaga keamanan dan privasi informan, maka peneliti pun menggunakan nama komunitas remaja muslim X. Cara ini dilakukan agar mampu menjangkau pengamatan online tentang adanya proses pencarian informasi pada masa pandemic COVID-19.

Pada teknik pengumpulan data berikutnya, wawancara mendalam dilakukan pada para informan yang menjadi anggota aktif komunitas remaja muslim $\mathrm{X}$ tersebut. Penelitian ini menggunakan teknik pengambilan informan yaitu teknik sampling purposive. Teknik ini digunakan dengan cara mengambil informan sesuai dengan kriteria penelitian peneliti, yaitu komunitas remaja muslim, dan menggunakan waktu untuk mengakses media sosiallebihtinggiintensitasnya.

Teknik analisis data dilakukan (Kaddi, Lestari, Adrian, 2020), yaitu reduksi data yang terkait COVID-19 dan komunitas remaja muslim, pengumpulan dataterkaitinformasidakwahIslam, dan penarikan kesimpulan terkait hasil penelitian.

\section{Hasil Penelitian dan Pembahasan}

Merujuk pada beberapa hasil penelitian terdahulu yang membahas komunikasi islami yang terjadi, penulis melihat adanya nilai kebaruan yang terdapat pada topik penelitian ini. Nilai kebaruan penelitian ini pada adanya pencarian informasi dakwah Islam yang tetap dilakukan pada masa pandemi COVID-19 oleh sebuah komunitas remaja muslim. Masa pandemi COVID-19 tidak menjadi penghalang bagi sebuah komunitas untuk menepis berbagai kendala psikologis yang dihadapi. Hal ini yang kemudian menjadi nilai kebaruan penelitian. Data terbaru yang dilansir dari Kalbaronline menyebutkan seorang pakar kesehatan mental, dr. Andri memaparkan kecemasan berlebihan yang terjadi terus menerus bisa menyebabkan masalah pada kesehatan fisik atau disebut dengan istilah psikosomatik. Ini biasa disebut juga sejenis masalah fisik yang disebabkan dan dipengaruhi oleh pikiran atau emosi, bukan karena adanya gangguan fisik (Fatria, 2020).

Sementara itu, pakar lain dalam kesehatan mental, Dimas Alwin, juga menegaskan pada masa pandemi COVID-19 ini penggunaan media sosial yang berlebihan bisa memicu meningkatnya gangguan kecemasan sosial. Pandemi COVID-19 mengharuskan masyarakat untuk melakukan karantina diri dan mengurangi aktivitas di luar rumah, maka komunikasi virtual dan penggunaan media sosial semakin meningkat. Perubahan sosial secara mendadak, cepat, dan terus menerus selama pandemiCOVID-19 inibisa menyebabkan rasa cemas dan panik (Fatria, 2020).

Data tersebut memperlihatkan signifikansi mengenai pandemi COVID-19 yang dihadapi sebagian individu di dunia ini. Peneliti juga mengamati fenomena menarik yang terjadi di Indonesia. Keberadaan sebuah komunitas muslim yang menghadapi masa pandemi COVID-19 dengan tetap melakukan pencarian informasi dakwah islam. Nilai orisinalitas pun terdapat dalam hasil penelitian peneliti yang menyebutkan adanya optimalisasi media digital sebagai ruang baru dalam pencarian informasi dakwah islam. Pada bagian ini, penulis akan memaparkan detail mengenai hasil penelitian tersebut. Hasil penelitian yang dilakukan peneliti menunjukkan beberapa point sebagai berikut: 
Alasan pencarian informasi dakwah islam berawal dari adanya kebanjiran informasi tentang pandemi COVID-19 sehingga mendorong komunitas tersebut untuk mencari solusinya.

Temuan ini merupakan hasil observasi dan wawancara kepada beberapa informan yang aktif dalam komunitas tersebut. Masa pandemic COVID-19 tidak menjadi penghalang bagi anggota komunitas muslim untuk tetap aktif dalam menuntut ilmu, utamanya tentang informasi dakwah islam yang tentu dikaitkan dengan fenomena COVID-19.

Salah satu informan, JQ yang aktif dalam komunitas muslim tersebut menyampaikan kepada penulis bahwa alasan pencarian informasi dakwah islam berawal dari kebanjiran informasi pandemic COVID-19 yang mendorong untuk bergerak dan mencari solusi.

"Kayak kita gak bisa diem aja, masa karena pandemi terus jadi gak bisa belajar gitu. Apalagi sekarang kan makin banyak info COVID-nya, kasusyangterjadigitu,jadiperlu dibentengi dengan ayo cari solusinya dalam islam kayak gimana." $\quad(J Q, 2020)$

Pernyataan tersebut memperlihatkan adanya alasan yang disampaikan terkait pencarian informasi dakwah islam. Hal tersebut juga sejalan dengan hasil temuan terdahulu dari China yang menyebutkan kondisi mental remaja yang menurun dan harus mendapat perhatian khusus pada masa pandemic COVID-19. Kebanjiran informasi yang berlebihan dapat membuat individu semakin bingung, sehingga JQ pun melakukan pencarian informasi dakwah islam bersama komunitasnya. "Betul, kita emang gak bisa berdiam diri kayak gakngapa-ngapain gitu, mesti bergerak harus ada aktivitas dakwah islam, kayak mencari info tentang dakwah ini jadi cara juga supaya kita dapat tetap mendapatkan solusi pada masa pandemic ini." (MM, 2020)

Informan lainnya yang juga sebagai penggiat aktif dalam komunitas tersebut juga membenarkan hal yang disampaikan oleh JQ. Pencarian informasi dakwah menjadi sebuah cara yang dapat meminimalisir adanya terpaan arus informasi yang membanjiri individu pada masa pandemi COVID-19. Oleh karena itu, hal tersebut diungkapkan sebagai temuan menarik dalam penelitian ini.

Selain itu, keadaan darurat kesehatan masyarakat adalah saat-saat stres bagi orang dan komunitas. Misalnya saja, mengelola rumor, menghilangkan informasi yang salah dan teori konspirasi, dan mengurangi ketakutan dan stigma yang ditujukan kepada orang dan tempat yang terkena dampak sangat penting untuk kesiapsiagaan dan pengendalian pandemi. Badan Kesehatan Internasional, termasuk WHO, diakui rumor, stigma, dan teori konspirasi sebagai ancaman yang muncul terhadap kesiapsiagaan dan pengendalian pandemi, dan, oleh karena itu, merekomendasikan tindakan pemantauan dan pengendalian yang sistematis (Islam, M. S., Sarkar, T., Khan, S. H., Mostofa Kamal, A. H., Hasan, S. M. M., Kabir, A., ... \& Chughtai, 2020).

Pada penyakit epidemi dan pandemi baru, deteksi, penilaian, dan tanggapan terhadap rumor, stigma, dan teori konspirasi serta dampaknya terhadap kesehatan masyarakat secara real time merupakan sebuah tantangan. Facebook, Twitter, dan surat kabar online telah diidentifikasi sebagai platform terbaik untuk memantau misinformasi dan menghilangkan rumor, stigma, dan teori konspirasi di kalangan masyarakat umum. Sejak permulaan pandemi COVID-19, pengguna media sosial telah berperan dalam semua tahap penerjemahan pengetahuan, termasuk COVID -19 morbiditas dan mortalitas, intervensi, penyebaran rumor dan teori konspirasi, dan stigma pelaporan. Oleh karena itu, mereka mengikuti dan memeriksa rumor, stigma, dan teori konspirasi terkait COVID-19 yang beredar di platform online, termasuk situs agen pemeriksa fakta, Facebook, Twitter, dan surat kabar online, serta dampaknya terhadap kesehatan masyarakat (Islam, M. S., Sarkar, T., Khan, S. H., Mostofa Kamal, A. H., Hasan, S. M. M., Kabir, A., \& Chughtai, 2020)

Jika merujuk pada temuan di atas, data yang diungkapkan memperkuat hasil penelitian penulis yang menunjukkan alasan pencarian informasi dakwah islam bagi komunitas muslim. Beredarnya ragam informasi tentang COVID-19 
Tabel 1 Penggunaan Media Sosial bagi Komunitas Remaja Muslim pada Masa Pandemik COVID-19

\begin{tabular}{|c|c|c|c|}
\hline No & Hasil Penelitian & $\begin{array}{c}\text { Media Sosial yang } \\
\text { digunakan }\end{array}$ & Hambatan \\
\hline 1. & $\begin{array}{l}\text { JQ: } \\
\text { "Kalau masa pandemi ini, kita liat } \\
\text { kondisi dulu pake media yang cocok } \\
\text { apa, kalau kegiatan dakwah-nya hanya } \\
\text { 3-4 orang, pake WhatsApp Video Call } \\
\text { aja, soalnya udah pada tau, bukan } \\
\text { media yang baru lagi..." }\end{array}$ & $\begin{array}{l}\text { WhatsApp Video Call } \\
\text { dipilih karena sesuai } \\
\text { dengan kebutuhan } \\
\text { untuk pencarian } \\
\text { informasi dakwah } \\
\text { pada 3-4 orang saja. }\end{array}$ & 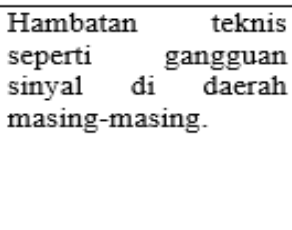 \\
\hline 2. & $\begin{array}{l}\text { MM: } \\
\text { "Kita juga ada agenda virtual kayak } \\
\text { pake zoom meeting gitu, semacam } \\
\text { kajian dakwah islam yang jumlah } \\
\text { pesertanya besar trus waktunya terbatas } \\
40 \text { menit-anu" }\end{array}$ & $\begin{array}{lr}\text { Zoom } & \begin{array}{r}\text { Meeting } \\
\text { digunakan }\end{array} \\
\text { menyesuaikan dengan } \\
\text { agenda } & \text { kegiatan } \\
\text { dakwah } & \text { yang } \\
\text { pesertanya } & \text { berjumlah } \\
\text { sekitar 30 } & \text { orang ke } \\
\text { atas. } & \end{array}$ & $\begin{array}{lr}\text { Hambatan } & \text { teknis } \\
\text { berupa penguasaan } \\
\text { perangkat } r \text { teknis } \\
\text { karenarram } \\
\text { terbiasa, gangguan } \\
\text { sinyal, dan kendala } \\
\text { teknis lainnya. }\end{array}$ \\
\hline 3. & $\begin{array}{l}\text { JQ: } \\
\text { "Kalau agendanya diskusi hal umum } \\
\text { saja, kita juga biasa menggunakan } \\
\text { whatsapp, group saja. Ini lebih } \\
\text { mudah..." }\end{array}$ & $\begin{array}{lr}\text { WhatsApp } & \text { Group } \\
\text { digunakan } & \text { karena } \\
\text { agenda } & \text { pencarian } \\
\text { informasi } & \text { berupa } \\
\text { diskusi kecil dalam } \\
\text { group. }\end{array}$ & $\begin{array}{l}\text { Hambatan waktu dan } \\
\text { teknis, misalnya jika } \\
\text { A membutuhkan } \\
\text { respon cepat, kadang } \\
\text { tertunda sehingga } \\
\text { dijawab beberapa jam } \\
\text { kemudian. }\end{array}$ \\
\hline 4. & $\begin{array}{l}\text { MM: } \\
\text { "Media sosial lain, paling kita juga } \\
\text { pakai google meet ya, yang gak } \\
\text { dibatasi durasi waktunya, maksudnya } \\
\text { bisa lebih dari } 40 \text { menit..." }\end{array}$ & $\begin{array}{l}\text { Google Meet juga } \\
\text { digunakan untuk } \\
\text { aktivitas dakwah } \\
\text { dalam jumlah peserta } \\
\text { di atas } 20 \text { orang. }\end{array}$ & $\begin{array}{l}\text { Hambatan waktu dan } \\
\text { teknis. }\end{array}$ \\
\hline
\end{tabular}

Sumber: Hasil Penelitian (2020)

membanjiri pikiran individu yang jika tidak memiliki upaya positif, akan berdampak pada kesehatan mental. Para informan dalam penelitian penulis mengungkapkan pencarian informasi dakwah islam sebagai upaya dalam mencegah kebanjiran informasi tentang pandemic COVID-19 yang dihadapi.

\section{Dampak masa pandemic COVID-19 menyebabkan komunitas remaja muslim aktif dan selektif dalam pencarian informasi dakwah islam melalui media online}

Hal lain yang menjadi temuan penelitian penulis adalah mengenai dampak yang ditimbulkan dari masa pandemi COVID-19 pada keberlangsungan komunitas muslim tersebut. Peneliti ingin mengungkapkan hal ini karena relevan dalam pencarian informasi yang dilakukan anggota komunitas tersebut. Adapun dampak yang dirasakan oleh anggota komunitas muslim tersebut pada sistem internal, yaitu menjadi aktif dan selektif dalam pencarian informasi dakwah islam melalui media online.
"Saya pribadi ngerasa berdampak besar banget ya, biasanya kita rutin punya agenda, tapi tentu bukan jadi penghalang meskipun masa pandemic yang sedang dihadapi sekarang. Jadi, kita juga mengalihkan kegiatan dakwah via online, misalnya via zoom meeting atau whatsapp video call juga. Ya, ini sebagai bentuk dakwah kami yang paling real..." (MM, 2020) Peneliti pun dapat mengaitkan dengan adanya penggunaan media online yang dioptimalkan oleh komunitas remaja muslim tersebut. Pada temuan ini, penulis pun mengkaji adanya dampak masa pandemi yang bukan berarti penghalang bagi komunitas tersebut, sehingga mereka pun beradaptasi menggunakan beragam media online. Hal ini menjadi temuan menarik, di mana komunitas remaja muslim $\mathrm{x}$ tetap berupaya melakukan aktivitas dakwah islam melalui berbagai media online.

Hal tersebut dapat diperkuat dengan adanya penelitian terdahulu yang menyebutkan bahwa menggunakan media sosial melalui perangkat 
Tabel 2 Tahapan Pencarian Informasi Dakwah Komunitas Remaja Muslim

\begin{tabular}{|c|c|c|c|c|}
\hline No & $\begin{array}{l}\text { Tahapan Pencarian } \\
\text { Informasi Dakwah }\end{array}$ & Pernyataan & $\begin{array}{c}\text { Elemen } \\
\text { Komunikasi }\end{array}$ & Media Online \\
\hline 1 & $\begin{array}{l}\text { Membuat pengelompokan } \\
\text { kebutuhan atau kategorisasi } \\
\text { informasi dakwah islam }\end{array}$ & $\begin{array}{l}\text { JQ yang } \\
\text { menyebutkan bahwa } \\
\text { mereka menentukan } \\
\text { kategorisasi } \\
\text { kebutuhan dakwah } \\
\text { terlebih dahulu }\end{array}$ & $\begin{array}{l}\text { Pesan/ Isi } \\
\text { informasi } \\
\text { dakwah } \\
\text { islam }\end{array}$ & $\begin{array}{l}\text { WhatsApp } \\
\text { Group }\end{array}$ \\
\hline 2 & $\begin{array}{l}\text { Setelah menemukan daftar } \\
\text { kategorisasi informasi } \\
\text { dakwah islam, mereka } \\
\text { membuat jadwal diskusi dan } \\
\text { memilih narasumber yang } \\
\text { tepat }\end{array}$ & $\begin{array}{l}\text { JQ mengatakan } \\
\text { adanya penentuan } \\
\text { jadwal dan } \\
\text { narasumber dalam } \\
\text { agenda pencarian } \\
\text { informasi dakwah } \\
\text { via online }\end{array}$ & $\begin{array}{l}\text { Komunikator } \\
\text { yang tepat } \\
\text { mengisi } \\
\text { informasi } \\
\text { tersebut }\end{array}$ & $\begin{array}{l}\text { WhatsApp Video } \\
\text { Call atau Zoom } \\
\text { Meeting }\end{array}$ \\
\hline 3 & $\begin{array}{l}\text { Memilih media dakwah } \\
\text { yang tepat sesuai dengan } \\
\text { jumlah peserta dan } \\
\text { kemungkinan } \\
\text { penggunaannya }\end{array}$ & $\begin{array}{l}\text { MM mengatakan } \\
\text { adanya penentuan } \\
\text { memilih media } \\
\text { online yang relevan } \\
\text { dengan kebutuhan }\end{array}$ & $\begin{array}{l}\text { Media dan } \\
\text { Komunikan }\end{array}$ & $\begin{array}{l}\text { WhatsApp } \\
\text { Group atau } \\
\text { WhatsApp Call }\end{array}$ \\
\hline
\end{tabular}

Sumber: Hasil Penelitian (2020)

seluler telah menjadi sumber utama penyebaran informasi; motivasi yang memengaruhi niat pengguna media sosial dan perilaku berbagi informasi yang sebenarnya perlu diperiksa lebih lanjut. Penelitian tersebut menguji berbagai motivasi terhadap perilaku berbagi informasi dalam konteks tertentu [penyakit virus corona 2019 (COVID-19)]. Penelitian tersebut mengumpulkan data dari 388 pekerja berpengetahuan melalui Google Formulir dan menerapkan pemodelan persamaan struktural untuk menguji hipotesis. Penelitian tersebut juga mencatat bahwa individu berperilaku serius terhadap informasi terkait krisis, karena mereka membagikan informasi COVID-19 di WhatsApp tidak hanya untuk dihibur dan mencari status atau informasi tetapi juga untuk membantu orang lain. Selain itu juga ada norma timbal balik, pengalihan kebiasaan, dan sosialisasi sebagai motivator yang meningkatkan sikap positif pengguna WhatsApp terhadap perilaku berbagi informasi COVID-19 (Islam, T., Mahmood,
K., Sadiq, M., Usman, B., \& Yousaf, 2020). Pada penelitian tersebut ditunjukkan bahwa media sosial pun kerap kali digunakan menjadi alat utama dalam mencari atau menyampaikan informasi pada masa pandemi saat ini. Tetapi dalam hal ini, penulis menemukan hasil penelitian bahwa sebuah komunitas remaja muslim yang juga berupaya melakukan penyesuaian proses dakwahnya dengan menggunakan media online.

Tabel 1 berisi deskripsi dari penggunaan media online pada masa pandemi bagi komunitas remaja muslim. Peneliti memaparkan gambaran hasil penelitian mengenai ragam media sosial yang digunakan komunitas remaja muslim pada masa pandemi COVID-19.

\section{Tahapan pencarian informasi dakwah islam dalam komunitas muslim $X$}

Dalam bagian ini, temuan berikutnya dari penelitian yang telah dilakukan adalah adanya proses pencarian informasi dakwah islam tersebut mulai dari mengelompokkan kebutuhan, 
membuat jadwal dan kelompok diskusi online, menggunakan wadah atau platform diskusi online seperti Google Meet, Zoom Meeting, dan WhatsApp Video Call. Meski bagaimanapun, masa pandemic COVID-19 telah mendorong komunitas tersebut tetap aktif dalam pencarian informasi dakwah islam.

Selain itu, peneliti juga menemukan adanya literatur yang menyebutkan tentang media sosial yang menjadi ancaman serius dalam menanggapi COVID-19. Laato (2020) menegaskan bahwa Organisasi Kesehatan Dunia telah menekankan adanya informasi yang salah - menyebar dengan cepat melalui media sosial - menimbulkan ancaman serius terhadap tanggapan COVID-19. Mereka juga mengembangkan dan menguji model penelitian yang berhipotesis mengapa orang membagikan informasi COVID-19 yang belum diverifikasi melalui media sosial. Temuan kami menunjukkan kepercayaan seseorang pada informasi online dan informasi yang dianggap berlebihan adalah prediktor kuat dari berbagi informasi yang tidak diverifikasi. Selain itu, faktor-faktor ini, bersama dengan keparahan dan kerentanan COVID-19 yang dirasakan seseorang memengaruhi cyberchondria. Wanita secara signifikan lebih mungkin menderita cyberchondria, namun pria lebih cenderung berbagi berita tanpa memeriksa fakta dari sumber mereka. Temuan kami menunjukkan bahwa untuk mengurangi penyebaran informasi yang salah dan cyberchondria COVID-19, langkah-langkah harus diambil untuk meningkatkan skeptisisme yang sehat terhadap berita kesehatan sekaligus menjaga dari informasi yang berlebihan (Laato, S., Islam, A. K. M., Islam, M. N., \& Whelan, 2020).

Jika merujuk pada literatur di atas, hasil penelitian penulis menjadi sebuah kebaruan yang ditemukan, terutama dalam hal menegaskan bahwa media sosial sebagai media digital yang digunakan secara optimal oleh komunitas remaja muslim tersebut. Penulis menemukan bahwa media online menjadi sebuah alat baru yang digunakan secara maksimal dalam hal pencarian informasi dakwah digital. Adapun tahap pencarian informasi tersebut, penulis menggambarkannya melalui tabel 2 .
Merujuk pada temuan penelitian, peneliti dapat mengklasifikasikan mengenai adanya penggunaan media online pada pencarian informasi dakwah bagi komunitas muslim. Adanya media online yang beragam menunjukkan proses pencarian informasi dakwah tersebut menggunakan adaptasi teknologi pada beragam media baru yang ada. Mereka menyesuaikan ruang media pada kemudahan akses dalam pencarian informasi dakwah islam tersebut.

\section{Analisis dari Information Seeking Theory}

Dalam topik penelitian ini, peneliti melihat adanya kesesuaian antara asumsi teori pencarian informasi atau information seeking theory dengan hasil penelitian ini. Perilaku pencarian informasi merupakan salah satu aspek literasi informasi.

Salah satu penelitian tentang perilaku informasi berkaitan dengan totalitas perilaku manusia dalam kaitannya dengan sumber dan saluran informasi, termasuk pencarian informasi aktif dan pasif, dan penggunaan informasi. Bagian dari penelitian tentang perilaku pencarian informasi. Area ini berkaitan dengan pencarian informasi secara purposif untuk memecahkan masalah informasi tertentu (Timmers, C. F., \& Glas, 2010). Pada artikelnya juga diungkapkan oleh Timmers (2010) bahwa pencarian informasi bervariasi dalam penekanannya pada aspek fisiologis, kognitif dan afektif dari perilaku pencarian informasi.

Penelitian yang dilakukan Rohmiyati (2018) juga dipaparkan tentang pencarian informasi bagi generasi milenial. Menurutnya, perilaku pencarian Informasi merupakan upaya menemukan dengan tujuan tertentu sebagai akibat dari adanya kebutuhan untuk memenuhi tujuan tertentu. Tidak hanya generasi milenial, tetapi juga setiap orang dari berbagai kalangan dapat berinteraksi dengan sistem informasi yang berkembang. Selain itu, ada juga sebuah teori perilaku pencarian informasi (Kuhlthau, 1991) yang menggambarkan kegiatan pencarian informasi sebagai sebuah proses konstruksi (pengembangan, pembangunan) yang dilalui seseorang dari tahap ketidakpastian (uncertainly) menuju pemahaman 
(understanding). Ada 6 tingkatan atau langkah yang terkandung dalam proses konstruksi ini, yaitu: awalan (initiation), pemilihan (selection), penjelajahan (exploration), penyusunan (formulation), pengumpulan (collection), dan penyajian (presentation) (Pendit, 2003).

Jika merujuk pada asumsi teori tersebut, maka hasil penelitian yang ditemukan relevan yaitu pada proses pencarian informasi yang dilakukan komunitas remaja muslim yang dilalui melalui proses konstruksi, mulai dari awalan, pemilihan, eksplorasi, penyusunan, pengumpulan, dan penyajian informasi dakwah islam pada masa pandemic COVID-19. Tahap awalan dilakukan dengan cara membuat pengelompokan kebutuhan atau kategorisasi informasi dakwah islam. Tahap selanjutnya adalah menemukan daftar kategorisasi informasi dakwah islam, mereka membuat jadwal diskusi dan memilih narasumber yang tepat. Tahap berikutnya adalah memilih media dakwah yang tepat sesuai dengan jumlah peserta dan kemungkinan penggunaannya.

Kegiatan tersebut dikatakan sebagai nilai kebaruan dalam penelitian ini karena pencarian informasi dakwah islam tetap dilakukan melalui media online, baik berupa media sosial atau sistem berjaringan lainnya, meskipun pada kenyataannya bahwa intensitas penggunaan media sosial yang meningkat tersebut membuat anggota komunitas remaja muslim mengalami tingkat kecemasan sosial, sebagaimana yang dipaparkan dalam data riset terbaru yang dilansir dari kalbaronline (Fatria, 2020).

\section{Simpulan}

Hasil penelitian yang dilakukan menunjukkan temuan baru mengenai sebuah komunitas remaja muslim yang berkiprah pada masa pandemi COVID-19. Temuan tersebut menunjukkan: 1) alasan pencarian informasi dakwah islam berawal dari adanya kebanjiran informasi tentang pandemi COVID-19 sehingga mendorong komunitas tersebut untuk mencari solusinya, 2) dampak masa pandemi COVID-19 menyebabkan komunitas remaja muslim aktif dan selektif dalam pencarian informasi dakwah islam melalui media online, 3) proses pencarian informasi dakwah islam tersebut mulai dari mengelompokkan kebutuhan, membuat jadwal dan kelompok diskusi online, menggunakan wadah atau platform diskusi online seperti Google Meet, Zoom Meeting, dan WA Video Call. Masa pandemi COVID-19 telah mendorong komunitas tersebut tetap aktif dalam pencarian informasi dakwah Islam. Penelitian ini memberikan kontribusi berupa rekomendasi kebijakan baru kepada para remaja dalam mencari informasi melalui media online harus selektif agar tidak merugikan lainnya.

\section{Daftar Pustaka}

Ahmed, S. T. (2020). Managing News Overload (MNO): The COVID-19 Infodemic. Information, 11(8), 375., 11(8). Creswell, J. W., \& Poth, C. N. (2016). Qualitative inquiry and research design: Choosing among five approaches. Sage publications.

Farooq, A., Laato, S., \& Islam, A. N. (2020). Impact of online information on self-isolation intention during the COVID-19 pandemic: cross-sectional study. Journal of Medical Internet Research, 22(5), E19128., 22(5).

Fatria, J. (2020). Waspadai Kecemasan Sosial di masa Pandemi Covid-19. https:// Www.Kalbaronline.Com/2020/11/09/ Waspadai - K e ce mas a n-Sosia $1-$ Di - M a s a - Pande mi - Covid - 19/. Fauzi,A. (2020). Problematika Dakwah di Tengah Pandemi COVID-19 Mewabah. (2020). Jurnal Al-Hikmah, 18(1), 27-36. https:// doi.org/10.35719/alhikmah.v18i1.22

Galanakis,C.M.(2020).(2020).TheFoodSystems in the Era of the Coronavirus (COVID-19) Pandemic Crisis. Foods, 9(4), 523. Hasan, J. (2020). Tantangan dan Arah Dakwah di Tengah Ancaman Pandemi COVID-19. Jurnal Peurawi, 3(2), 4660. http://dx.doi.org/10.22373/jp.v3i2.7919

Hasna, S. (2020). Infodemik: Banjir Informasi di Masa Pandemi Covid-19. https://ibtimes.id/infodemik-banjirinformasi-di-masa-pandemi-covid-19/. https://ibtimes.id/infodemik-banjirinformasi-di-masa-pandemi-covid-19/ 
Islam, A. N., Laato, S., Talukder, S., \& Sutinen, E. (2020). Misinformation sharing and social media fatigue during COVID-19: An affordance and cognitive load perspective. Technological Forecasting and Social Change, 159, 120201. Islam, M. S., Sarkar, T., Khan, S. H., Mostofa Kamal, A. H., Hasan, S. M. M., Kabir, A., ... \& Chughtai, A. A. (2020). COVID-19Related Infodemic and Its Impact on Public Health: A Global Social Media Analysis. The American Journal of Tropical Medicine and Hygiene, Tpmd200812. Islam, T., Mahmood, K., Sadiq, M., Usman, B., \& Yousaf, S. U. (2020). Understanding Knowledgeable Workers' Behavior Toward COVID-19 Information Sharing Through WhatsApp in Pakistan. Frontiers in Psychology, 11.

Kaddi, S., Lestari, P., \& Adrian, D. (2020). Komunikasi Keluarga Dalam Pencegahan Coronavirus Disease 2019. Jurnal Ilmu Komunikasi, 18(1), 63-74. https:// doi.org/10.31315/jik.v18i1.3701

Kuhlthau, K. (1991). , "inside the search process: information seeking from the user's perspective". Journal of the American Society For Information Science. No 42, Vol.5, 1991. Laato, S., Islam, A. K. M., Islam, M. N., \& Whelan, E. (2020). (2020). Why do people share misinformation during the Covid-19 pandemic?. ArXiv Preprint ArXiv:2004.09600.
Muchlis, S. (2020). WhatsApp sebagai Media Dakwah Penyuluh Agama Islan pada Masa Pandemi COVID-19. Jurnal Simbolika, 6(2), 134-142. https://doi. org/10.31289/simbollika.v6i2.4033 Pendit, P.L.(2003).Penelitian Ilmu Perpustakaan dan Informasi: suatu pengantar diskusi epistemologi dan metodologi, Jakarta: JIP Fak Sastra UI, 2003.

Rohmiyati, Y. (2018). Model Perilaku Pencarian Informasi Generasi Milenial. Anuva: Jurnal Kajian Budaya, Perpustakaan, Dan Informasi, 2(4), 387-392.

Saud, M., Mashud, M. I., \& Ida, R. (2020). Usage of social media during the pandemic: Seeking support and awareness about COVID-19 through social media platforms. Journal of Public Affairs, 20(4), E2417.

Setyowati \& Cahya, A. (2020). Peran Dakwah Daring untuk Menjaga Solidaritas Sosial di Masa Pandemi COVID-19. Academica, 4(2), 295-310. Diakses dari http://ejournal.iainsurakarta.ac.id/ index.php/academica/article/view/3175

Sujarwoko, D. (2020). Pasien Kecemasan Meningkat. https:/Www.Republika.Id/ Posts/10770/Pasien-Kecemasan-Meningkat. Timmers, C. F., \& Glas, C. A. (2010). (2010). Developing scales for information-seeking behaviour. Journal of Documentation. Zaenuri A. (2020). Konsepsi Fikih Dakwah Jama'ah Tabligh pada Masa Pandemi COVID-19: Telaah Gerakan Dakwah Jama'ah Tabligh Gorontalo. JIL: Journal of Islamic Law. 1(2), 135-157. https://doi.org/10.24260/jil.v1i2.68 